International Journal of Environmental Research and

Article

www.mdpi.com/journal/ijerph

\title{
Biosurfactant Production by Bacillus salmalaya for Lubricating Oil Solubilization and Biodegradation
}

\author{
Arezoo Dadrasnia ${ }^{1}$ and Salmah Ismail ${ }^{1, *}$ \\ 1 Department of Biohealth Science, Institute of Biological Sciences, Faculty of Science, University of \\ Malaya, Kuala Lumpur 50603, Malaysia; E-Mail: are.dadrasnia@gmail.com \\ * Author to whom correspondence should be addressed; E-mail: salmah_r@um.edu.my; \\ Tel.: +60-379-677-150.
}

Academic Editors: Rao Bhamidiammarri and Kiran Tota-Maharaj

Received: 24 June 2015 / Accepted: 27 July 2015 / Published: 19 August 2015

\begin{abstract}
This study investigated the capability of a biosurfactant produced by a novel strain of Bacillus salmalaya to enhance the biodegradation rates and bioavailability of organic contaminants. The biosurfactant produced by cultured strain 139SI showed high physicochemical properties and surface activity in the selected medium. The biosurfactant exhibited a high emulsification index and a positive result in the drop collapse test, with the results demonstrating the wetting activity of the biosurfactant and its potential to produce surface-active molecules. Strain 139SI can significantly reduce the surface tension (ST) from 70.5 to $27 \mathrm{mN} / \mathrm{m}$, with a critical micelle concentration of $0.4 \%$. Moreover, lubricating oil at $2 \%$ (v/v) was degraded on Day 20 (71.5). Furthermore, the biosurfactant demonstrated high stability at different ranges of salinity, $\mathrm{pH}$, and temperature. Overall, the results indicated the potential use of B. salmalaya 139SI in environmental remediation processes.
\end{abstract}

Keywords: biosurfactant; bioremediation; lubricating oil; solubilization activity

\section{Introduction}

Petroleum consumption is rapidly increasing in industry, and as a result, large amounts of hydrocarbons are discharged annually into the environment, either accidentally or deliberately. In addition, many small spills occur during oil recovery, transport, and refining [1]. Recently, the development and 
implementation of innovative and environmentally friendly technologies to degrade and/or remove these organic compounds have gained increasing attention. Many microbial species are reported to be effective in the breakdown of organic compounds, which are used as energy sources by these microorganisms. Moreover, the use of biocompounds has emerged as a promising method to enhance and improve the effectiveness of bioremediation processes [2-5]. In this model, biosurfactant molecules act as mediators that increase the mass transfer rate by making hydrophobic pollutants more bioavailable to microorganisms and may also induce changes in the properties of cellular membranes, resulting in increased microbial adherence [4]. This mechanism is of importance when two immiscible phases (oil and water) are present and direct substrate uptake is plausible.

Biosurfactants or surface-active agents are amphipathic molecules comprising an important class of chemical compounds [6]. Such biosurfactants are biologically extracted as components of the bacterial or yeast cell membrane; they have low toxicity and are biodegradable because they can reduce interfacial tension, surface tension (ST), and the critical micelle concentration (CMC). Furthermore, these biocompounds can survive in a wide range of $\mathrm{pH}$ and temperature conditions and to some extent can affect interfaces [7]. In addition, because biosurfactants consist of naturally occurring molecules, such as lipopeptides, glycolipids, fatty acids, and lipoproteins, they are more suitable for environmental and petrochemical applications than synthetic and traditional chemical surfactants $[8,9]$. Bacterial strains belonging to genera Bacillus and Pseudomonas typically produce lipopeptide biosurfactants; Table 1 shows the main types of biosurfactants produced by some microorganisms [10]. Two mechanisms can be employed to enhance hydrocarbon degradation with biosurfactants: (1) improving the transfer of contaminants into the aqueous phase by interaction with soluble contaminants; and (2) increasing the availability and solubility of hydrocarbons by reducing ST. These mechanisms allow contact of the bacterial cell surface with hydrophobic substrates [2].

Table 1. Microbial biosurfactants.

\begin{tabular}{cc}
\hline Microorganism & Biosurfactant \\
\hline Pseudomonas $s p$. & Rhamnolipids \\
Rhodococcus $s$. & Trehalose lipids \\
Candida sp. & Mannosyl erythritol lipid \\
Candida bogoriensis & Sophorolipid \\
Corynebacterium lepus & Corynemycolic acids \\
Candida petrophilum & Peptidolipid \\
Bacillus subtilis & Cyclic lipopeptide \\
Bacillus licheniformis & Cyclic lipopeptide \\
Candida tropicalis & Mannan-fatty acid complex \\
\hline
\end{tabular}

Many microbial ecologists have reported the potential of various Bacillus species to produce good biosurfactants under aerobic and anaerobic conditions that can be used in the food industry [8,11]. From an economic perspective, the application of low-cost substrates is an important factor for successfully developing biosurfactant production.

The present study aimed to evaluate the stability of a biosurfactant produced by B. salmalaya 139SI under different environmental conditions and to characterize its properties. This study also investigated the capacity of the biosurfactant to solubilize and facilitate the degradation of oil and to reduce ST at 
different environmental conditions. Most importantly, the ability of the biosurfactant to biodegrade lubricating oil from contaminated water was evaluated.

\section{Materials and Methods}

\subsection{Microorganism Isolation}

Bacterial cells were harvested, and genomic DNA was extracted using NucleoSpin Tissue in accordance with the manufacturer's instructions. Selected 16S rRNA universal primers, namely, 27Forward (5'-AGAGTTTGATCMTGGCTCAG-3') and 1492Reverse (5'- GGTTACCTTGTTACGACTT -3'), were used to amplify the $16 \mathrm{~S}$ rRNA region [12].

\subsection{Culture Medium and Biosurfactant Preparation}

Bacillus salmalaya 139SI was cultured in $1 \mathrm{~L}$ of brain-heart infusion (BHI) medium containing $5 \mathrm{~g} / \mathrm{L} \mathrm{KCl}, 3 \mathrm{~g} / \mathrm{L}$ dextrose, $2.5 \mathrm{~g} / \mathrm{L} \mathrm{Na}_{2} \mathrm{HPO}_{4}, 14.5 \mathrm{~g} / \mathrm{L}$ gelatin, $6 \mathrm{~g} / \mathrm{L} \mathrm{BHI}$, and $6 \mathrm{~g} / \mathrm{L}$ peptic digest of animal tissue in a shaking incubator at $150 \mathrm{rpm}$ for $72 \mathrm{~h}$ at $35^{\circ} \mathrm{C}$. The biosurfactant was produced using the method described by Rufino et al., [7,13]. The $72 \mathrm{~h}$ culture was centrifuged $(8000 \times \mathrm{g}$ for $15 \mathrm{~min})$ and filtered through a Whatman no.1 filter. The cell-free broth was concentrated by freeze-drying (stored at $-20^{\circ} \mathrm{C}$ ) and extracted twice with chloroform in a separatory funnel at $28^{\circ} \mathrm{C}$. For measurement of carbohydrates (reducing sugars), a microtiter plate adaptation of the dinitrosalicylic acid (DNS) colorimetric method was used [14]. The protein concentration of the isolated biosurfactant was estimated using the DC Protein Assay Reagents Package ${ }^{\mathrm{TM}}$ (BioRad). Different parameters, such as $\mathrm{pH}$, biosurfactant production, growth kinetics, and ST, were monitored at regular intervals.

\subsection{Determination of Biomass}

Approximately $10 \mathrm{~mL}$ of the sample was transferred to a pre-weighted tube and centrifuged at $8000 \mathrm{rpm}$ for $30 \mathrm{~min}$. The cell pellets were washed twice and dried for $48 \mathrm{~h}$ at $90^{\circ} \mathrm{C}$. All assays were performed in triplicate.

\subsection{Drop Collapse and Oil Displacement Tests}

Drop collapse and oil displacement tests were conducted using the method described by Ayed et al. [2]. Briefly, $2 \mu \mathrm{L}$ of lubricating oil was added to 96 -well plates. After $1 \mathrm{~h}$ equilibrium at $35^{\circ} \mathrm{C}, 5 \mu \mathrm{L}$ of the supernatant obtained from the culture was added to the oil surface. Distilled water was used as control. After $1 \mathrm{~min}$, the shape of the drop was observed. Bead-like and collapsed drops indicated negative and positive results, respectively. To measure the clear zone diameter, an oil displacement test was performed by dropping $20 \mu \mathrm{L}$ of oil onto $50 \mathrm{~mL}$ of distilled water in a Petri dish followed by the addition of $10 \mu \mathrm{L}$ of the supernatant. The clear zone diameter was determined and compared with that of the control. 


\subsection{Determination of Emulsification Activity}

The emulsification index ( $\left.\mathrm{EI}_{24}\right)$ was measured using a previously described method [15], with slight modifications, at $25{ }^{\circ} \mathrm{C}$ by vortexing $4 \mathrm{~mL}$ of the biosurfactant and lubricating oil for $5 \mathrm{~min}$. After $24 \mathrm{~h}$, EI was calculated as follows:

$$
\mathrm{EI}_{24}(\%)=\alpha / \beta \times 100
$$

where $\alpha$ and $\beta$ represent the height of the emulsified layer and the total height, respectively.

\subsection{Determination of Bacterial Growth and Surface Tension Reduction}

After 7 days of incubation, bacterial growth was determined via spectroscopy at $600 \mathrm{~nm}$ to assess nutrient and physical parameters. Cultures were centrifuged at $8000 \mathrm{rpm}$ for $30 \mathrm{~min}$ at $4{ }^{\circ} \mathrm{C}$, and the cell-free supernatants were used to determine ST with a tensiometer $(\mathrm{mN} / \mathrm{m})$. The ST percentage was calculated as follows [16]:

$$
\mathrm{ST} \text { reduction }(\%)=\mathrm{Sc}-\mathrm{Ss} / \mathrm{Sc} \times 100
$$

where Sc is the ST of the control and Ss is the ST of the sample.

\subsection{Critical Micelle Concentration of the Biosurfactant}

Dilutions of the biosurfactant in distillate water were prepared to determine CMC up to a constant $\mathrm{ST}$ value. CMC was determined as $\mathrm{mg} / \mathrm{L}$ by plotting the ST concentration against the ST value.

\subsection{Fourier Transform Infrared Spectroscopy}

To understand the overall chemical nature of the extracted biosurfactant, Fourier transform infrared spectroscopy (FTIR) was employed, which helps to explore the functional groups and chemical bonds present in a crude extract. The analysis was performed using spectrum 4000, US. Samples were prepared via homogeneous dispersal of $1 \mathrm{mg}$ of the biosurfactant sample in pellets of potassium bromide powder at a ratio of 1:100 and pressed under 10 tons of pressure. IR spectra were collected over the 600 and $4000 \mathrm{~cm}^{-1}$ range.

\subsection{Stability Analyses}

Du Nouy ring methodology was used to measure ST (KSV Sigma 702, Finland); the ST of deionized water was also measured $(70.5 \mathrm{mN} / \mathrm{m})$ to calibrate the tensiometer. Up to $25 \mathrm{~mL}$ of each surfactant solution was placed in a clean beaker, and ST was measured using a platinum wire ring. To increase the accuracy of the experiment, the ST measurements were performed at room temperature $\left(22^{\circ} \mathrm{C}\right)$.

\subsection{1. $\mathrm{pH}$ and Temperature}

Approximately $10 \%(\mathrm{v} / \mathrm{v})$ of inoculum was incubated in a $100 \mathrm{~mL}$ flask containing $50 \mathrm{~mL}$ of BHI and incubated at $35{ }^{\circ} \mathrm{C}$ in an orbital shaker at $150 \mathrm{rpm}$ for 3 days. Different $\mathrm{pH}$ values (2 to 10$)$ were 
used to determine the optimal $\mathrm{pH}$. Afterward, the inoculum was adjusted at an optimized $\mathrm{pH}$ following incubation at $200 \mathrm{rpm}$ for 7 days at different temperatures $\left(20^{\circ} \mathrm{C}\right.$ to $\left.50{ }^{\circ} \mathrm{C}\right)$.

\subsubsection{Carbon, Nitrogen, and Phosphorus Sources}

The effects of various carbon sources (olive, sunflower, transformer, glycerol, and vegetable oils) on bacterial growth and biosurfactant production were investigated. A final concentration of $1 \%(\mathrm{v} / \mathrm{v})$ of each source was sterilized and filtered $(0.2 \mu \mathrm{m}$ pore size $)$ and then added separately to evaluate the effects on biosurfactant production. The cultures were placed in a shaking incubator at $200 \mathrm{rpm}$ for 7 days at $35^{\circ} \mathrm{C}$. The effect of salinity on ST was tested by fixing the optimized $\mathrm{pH}$ value and adjusting different concentrations of $\mathrm{NaH}_{2} \mathrm{PO}_{4}(0,7$, and $15 \mathrm{~g} / \mathrm{L}),\left(\mathrm{NH}_{4}\right)_{2} \mathrm{SO}_{4}(0,1$, and $2 \mathrm{~g} / \mathrm{L})$, and $\mathrm{NaCl}(20,40$, and $60 \mathrm{~g} / \mathrm{L})$.

\subsection{Lubricating Oil Solubilization Test}

A solubility assay for lubricating oil was performed in the presence of different biosurfactant concentrations $(0.1 \mathrm{~g} / \mathrm{L}$ to $2.4 \mathrm{~g} / \mathrm{L})$. Up to $300 \mu \mathrm{L}$ of lubricating oil was added (to a final volume of $30 \mathrm{~mL}$ ) to the biosurfactant in test tubes containing $\mathrm{HCl}$ buffer. The tubes were capped and incubated in an orbital shaker $\left(150 \mathrm{rpm}\right.$ at $\left.35^{\circ} \mathrm{C}\right)$. After $24 \mathrm{~h}$, the residual oil at the surface of the tubes was separated and transferred to clean tubes containing the same amount of n-hexane. The tubes were vortexed for $3 \mathrm{~min}$ and centrifuged for $20 \mathrm{~min}$ at $80,000 \mathrm{rpm}$. The oil concentration was measured at $300 \mathrm{~nm}$. Control samples, which contained no biosurfactant, were subjected to the same method. All assays were performed in triplicate.

$$
\text { Percentage of solubilization }=\mathrm{C}_{\text {lubricating oil }}-\mathrm{C}_{\text {control }} / \mathrm{C}_{\text {inital }} \times 100
$$

where Clubricating oil is the oil concentration after extraction from the hexane solution; $\mathrm{C}_{\text {control }}$ is the oil concentration in the control: and $\mathrm{C}_{\text {initial }}$ is the oil concentration prior to the solubilization assay.

\section{Lubricating Oil Degradation Assay}

The biosurfactant produced by B. salmalaya 139SI was examined to determine the biodegradation rate. Strain 139SI was grown in BHI broth $\left(150 \mathrm{rpm}\right.$ at $\left.37^{\circ} \mathrm{C}\right)$ to achieve $\mathrm{OD}_{600}$ of 1 , and $10 \%(\mathrm{w} / \mathrm{v})$ was used as seed culture for biosurfactant production. The bacterial cells were harvested by centrifugation and resuspended in sterilized mineral salt medium (MSM) containing $1.8 \mathrm{~g} \mathrm{~K}_{2} \mathrm{HPO}_{4}$, $0.1 \mathrm{~g} \mathrm{NaCl}, 1.2 \mathrm{~g} \mathrm{KH}_{2} \mathrm{PO}_{4}, 0.01 \mathrm{~g} \mathrm{FeSO}_{4} .7 \mathrm{H}_{2} \mathrm{O}, 4 \mathrm{~g} \mathrm{NH} 4 \mathrm{Cl}$, and $0.2 \mathrm{~g} \mathrm{MgSO}_{4} .7 \mathrm{H}_{2} \mathrm{O}$. To assess the biodegradation of lubricating oil $(2 \% \mathrm{v} / \mathrm{v})$, inoculum $(1 \mathrm{~g} / \mathrm{L}$ of strain $139 \mathrm{SI})$ was added to $50 \mathrm{~mL}$ of sterilized MSM

Uninoculated medium was used for the control treatment. The flasks were incubated in a shaking incubator maintained at $35{ }^{\circ} \mathrm{C}$ for 24 days at $150 \mathrm{rpm}$. The residual oil was extracted twice using $50 \mathrm{~mL}$ of $n$-hexane as the solvent and then dried with anhydrous sodium sulfate. The solvent was evaporated using a rotary evaporator, and the weight of the residual oil was measured and recorded. The percentage of oil degradation was calculated as follows:

$$
\text { YPH degradation }(\%)=\mathrm{TC}-\mathrm{TT} / \mathrm{TC} \times 100
$$


where TPH is the total petroleum hydrocarbon, TC is the TPH in the control sample, and TT is the TPH in the treatment. Additionally, the extracted hydrocarbon was analyzed by gas chromatography with a helium carrier gas flow of $1.27 \mathrm{~mL} / \mathrm{min}$. The column oven was initially held at $50{ }^{\circ} \mathrm{C}$ for $2 \mathrm{~min}$, increased to $300^{\circ} \mathrm{C}$ at a rate of $6^{\circ} \mathrm{C} \mathrm{min}^{-1}$, and held for $16 \mathrm{~min}$.

\subsection{Statistical Analyses}

The means of the treatments were evaluated by ANOVA using a general linear model (SPSS 18). Duncan's multiple range tests were performed to determine the level of significance $(p<0.05)$.

\section{Results and Discussion}

\subsection{Biosurfactant Activity Assay Tests}

Drop collapse and oil spreading techniques were used because of their low cost, simplicity, and quick implementation. The positive result obtained in the drop collapse test revealed the wetting activity of the biosurfactant and its potential to produce surface-active molecules. The oil displacement test is an index to predict the surfactant production caused by the decrease in the oil-water interfacial tension [2], and the area of oil displacement $\left(75 \mathrm{~cm}^{2}\right)$ indicated high activity of the biosurfactant produced by B. salmalaya 139SI. The emulsification index ( $\left.\% \mathrm{E}_{24}\right)$ of 139SI decreased at low $\mathrm{pH}$, and the highest emulsification $(65 \pm 1.1 \%)$ was observed between $\mathrm{pH} 5$ and 8. Cunha et al., [17] used gasoline as a carbon source to produce a biosurfactant during fermentation at $\mathrm{pH}$ 6.0. Each microorganism is adapted to a specific $\mathrm{pH}$, depending on the relevant type of biosurfactant, and such specificity facilitates the bioavailability of organic compounds to bacteria, accelerating hydrocarbon degradation. Additionally, the emulsion activity of strain 139SI was stable for two weeks at room temperature. The profiles of biomass at $600 \mathrm{~nm}$ and ST during five days of incubation time are shown in Figure 1A; growth was carried out at $32{ }^{\circ} \mathrm{C}$ and $150 \mathrm{rpm}$. The ST of the biosurfactant rapidly decreased after cultivation and became constant after $48 \mathrm{~h}(36.5 \mathrm{mN} / \mathrm{m})$. Maximum growth was observed after two days, followed by a steady decrease until the end of the incubation (120 h). Furthermore, several authors have reported that the fluid ST did not vary once micelle formation began. Ruggeri et al., [18] indicated that quantitative analyses, including ST determination, are reliable methods for determining the solubility of biosurfactants in media. If ST is reduced to $<40 \mathrm{mN} / \mathrm{m}$ and/or at least $50 \%$ emulsification is observed after $24 \mathrm{~h}$, the strain can be considered to be a biosurfactant producer. Nitschke and Pastore [19] reported that B. subtilis is one of the most effective Bacillus species in this regard because it can reduce ST from 72 to $27 \mathrm{mN} / \mathrm{m}$. In the present study, B. salmalaya 139SI showed positive results in all the quantitative tests. The carbohydrate and protein contents of strain $139 \mathrm{SI}$ were $0.72 \mathrm{~g} / \mathrm{L}$ and $1.9 \mathrm{~g} / \mathrm{L}$, respectively. 

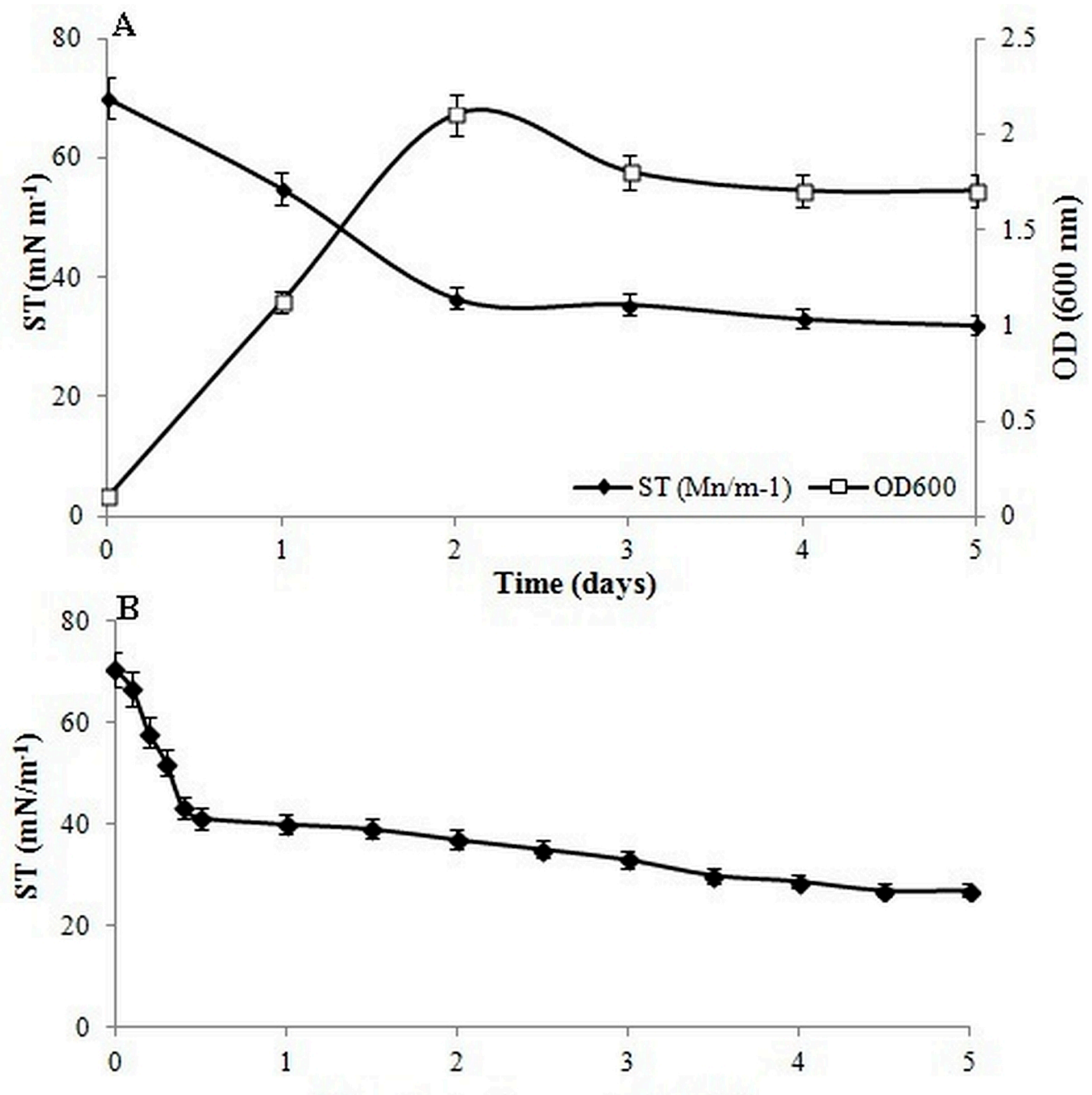

Biosurfactant concentration (\%)

Figure 1. (A) Surface tension reduction and time course of cell growth in brain-heart infusion (BHI) medium. (B) Surface tension versus concentration of biosurfactant produced by $B$. salmalaya 139 SI. Vertical bars indicate SE $(n=3)$.

\subsection{Critical Micelle Concentration}

To establish the CMC of the purified biosurfactant from B. salmalaya 139SI, the relationship between biosurfactant concentration and surface tension was determined (Figure 1B). The surface activity of a biosurfactant depends on its ability to decrease the formation of a stable emulsion, as well as its ST and CMC values [20]. The minimum biosurfactant concentration or CMC should be determined in order to obtain maximum ST reduction. With increasing biosurfactant concentration, ST was significantly reduced from $70.5 \mathrm{mN} / \mathrm{m}$ to $27 \mathrm{mN} / \mathrm{m}$ and then remained constant to a CMC value of 5\%. This CMC value of the biosurfactant produced by B. salmalaya 139SI was much lower than that of a chemical surfactant, which indicated that the CMC was reached. The length of the fatty acid chain also affects CMC, with a low CMC being caused by long-chain fatty acids [21]. The reported CMC values for different types of biosurfactants produced by Bacillus species are within this range [22-24]. Bacillus show smaller CMC and ST values than other genera, such as Candida and Pseudomonas. Ayed et al., [2] reported the minimum ST and CMC values for B. amyloliquefaciens 
An6 $(29 \mathrm{mN} / \mathrm{m})$, and the biosurfactants produced by B. subtilis B20 and B. subtilis BS-37 were able to reduce the $\mathrm{ST}$ and interfacial tension to 25 and $28 \mathrm{mN} / \mathrm{m}$, respectively [2,22].

\subsection{Fourier Transform Infrared Spectroscopy}

As a result of $\mathrm{C}-\mathrm{H}$ stretching vibrations, a broad absorbance peak with variable wave numbers was observed (Figure 2). This is typical of carbon compounds containing amino groups. The sharp absorbance peaks at 1041 and $1450 \mathrm{~cm}^{-1}$ are indicative of aliphatic chains $\left(-\mathrm{CH}_{3}\right.$ and $\left.-\mathrm{CH}_{2}-\right)$, and these peaks reflect the presence of alkyl chains in a compound. The peaks at approximately $3269 \mathrm{~cm}^{-1}$ indicate the $\mathrm{C}-\mathrm{H}$ bonds of $-\mathrm{CH}_{2}$ groups. The strong band observed at $1619.31 \mathrm{~cm}^{-1}$ is attributed to a carbonyl group; the presence of $\mathrm{C}=\mathrm{O}$ bonds causing $\mathrm{C}=\mathrm{O}$ stretching vibrations, which leads to absorbance peaks in these regions. The FTIR spectrum suggests the production of a lipopeptide biosurfactant.

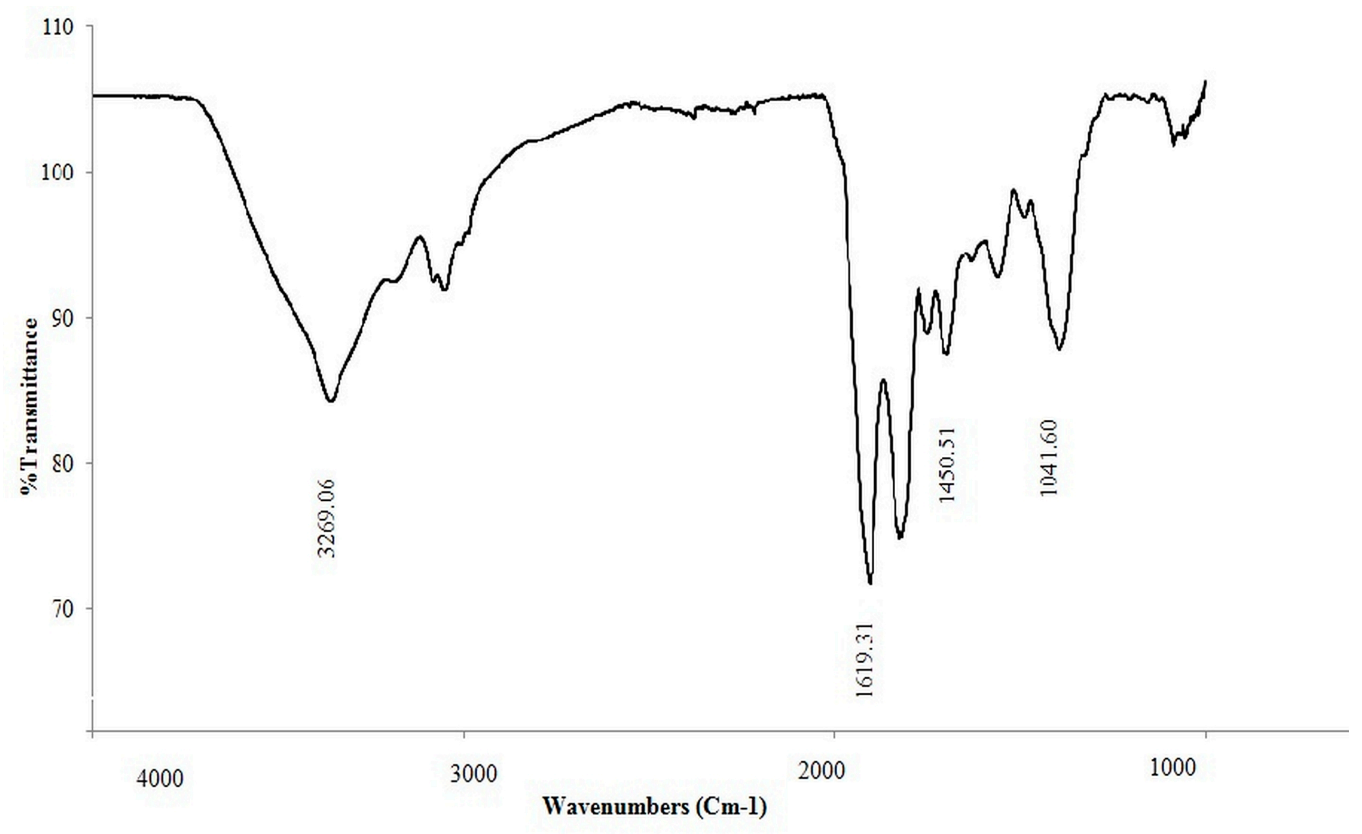

Figure 2. Fourier transform infrared spectra (FTIR) of the biosurfactant produced by Bacillus salmalaya.

\subsection{Stability Studies}

As many factors influence the effectiveness of biosurfactant activities, these parameters must be examined to confirm the application of a biosurfactant during remediation. In the present study, a wide range of $\mathrm{pH}$ and temperature was tested to evaluate the stability of $B$. salmalaya 139SI to grow and produce biosurfactants. As shown in Figure $3 \mathrm{~A}$, a $\mathrm{pH}$ of 6.5 was the optimal value for biosurfactant production with the highest rate of ST reduction $(38.5 \pm 2.1 \%)$ when compared with the treatment without inoculation. The results also showed a low level of biosurfactant production at acidic $\mathrm{pH}(<5)$ and alkaline $\mathrm{pH}(>9)$. Various species produce biosurfactants at different $\mathrm{pH}$ values. Bacillus salmalaya 139SI produced the maximum amount of biosurfactant at $\mathrm{pH} 6.5$ when incubated at $36{ }^{\circ} \mathrm{C}$, which was significantly different from the production at other temperatures. The lowest ST was produced at $20{ }^{\circ} \mathrm{C}$ (Figure 3B); ST sharply increased when the temperature increased up to $36{ }^{\circ} \mathrm{C}$ and 
then gradually decreased and remained constant at $46{ }^{\circ} \mathrm{C}$. Thus, temperature affects biosurfactant production, a finding that is consistent with the results of other studies [3,25-27]. Nonetheless, different Bacillus strains present various optimal temperatures and $\mathrm{pH}$ values.

The effect of different carbon sources on ST was evaluated using 1\% (v/v) olive, sunflower, transformer, glycerol, and vegetable oils. As shown in Figure 3C, a significant reduction in ST was observed with particular carbon sources. The lowest and highest ST reduction rates were found for the transformer and sunflower oils, with values of 33.5 and $71.1 \%$, respectively (Figure 3C). Moreover, ST decreased with olive, vegetable, and glycerol oils, to 59.6, 57.3, and 48.6\%, respectively. This result is in contrast with that of Zhang et al. [28] who reported the ability of $P$. aeruginosa to produce a biosurfactant in $30 \mathrm{~g} / \mathrm{L}$ glycerol compared with paraffin and vegetable oil. In the present study, the reduction of ST in glycerol was less than that in the other carbon sources, which may be ascribed to the different bacterial genera used, and the various optimal $\mathrm{pH}$ and temperature values for biosurfactant production. The effects of salt and $\mathrm{N}$ and $\mathrm{P}$ concentrations on biosurfactant production were also assessed. Given the relatively high salinity in oil refineries, halophilic bacteria should be used during oil recovery. $\mathrm{N}$ and $\mathrm{P}$ concentrations and the nutrient formulation are important parameters to ensure rapid bacterial growth and biosurfactant production. Therefore, the possibility of biosurfactant production depends on the complex structure of the biosurfactant itself and on the concentrations of salts, $\mathrm{N}$, and $\mathrm{P}$. The results illustrated that the percentage of ST reduction was enhanced when the concentration of $\mathrm{NaH}_{2} \mathrm{PO}_{4}$ as a source of $\mathrm{P}$ increased to $15 \mathrm{~g} / \mathrm{L}$ (Figure 4A); this finding indicated the positive effect of $\mathrm{P}$ on biosurfactant production. The maximum $\mathrm{ST}$ reduction (63.91\%) was observed when $15 \mathrm{~g} / \mathrm{L} \mathrm{NaH} \mathrm{NO}_{4}$ and $40 \mathrm{~g} / \mathrm{L} \mathrm{NaCl}$ were added; in contrast, the percentage of ST reduction decreased to $45.9 \%$ with the addition of $60 \mathrm{~g} / \mathrm{L} \mathrm{NaCl}$ and $15 \mathrm{~g} / \mathrm{L}$ $\mathrm{NaH}_{2} \mathrm{PO}_{4}$. This result is in very close agreement with the findings of Huszcza and Burczyk [29], who reported that the biosurfactant activity produced by $B$. coagulans was enhanced with the addition of salts. In addition, the maximum activity of the biosurfactant produced by $B$. subtilis was achieved with the addition of $15 \% \mathrm{NaCl}$ [30]. The current results also indicated that B. salmalaya can grow under conditions of high salinity. The highest percentage of ST reduction $(53.3 \%)$ with the simultaneous application of $\mathrm{NaCl}$ and $\left(\mathrm{NH}_{4}\right)_{2} \mathrm{PO}_{4}$ was observed at concentrations of 40 and $1 \mathrm{~g} / \mathrm{L}$, respectively (Figure 4B). As shown in Figure 4C, to decrease ST, the optimal concentration of $\mathrm{NaH}_{2} \mathrm{PO}_{4}$ was $15 \mathrm{~g} / \mathrm{L}$ without the addition of $\left(\mathrm{NH}_{4}\right)_{2} \mathrm{PO}_{4}$. These results showed the inhibiting effect of low and high concentrations of $\mathrm{N}, \mathrm{P}$, and salts on the biological activities of strain 139SI. However, the lowest supernatant ST reduction (28.5\%) was observed when the concentrations of $\mathrm{NaCl}, \mathrm{NaH}_{2} \mathrm{PO}_{4}$, and $\left(\mathrm{NH}_{4}\right)_{2} \mathrm{PO}_{4}$ were increased to $60,7.5$, and $2 \mathrm{~g} / \mathrm{L}$, respectively. Thus, increasing the concentration of $\mathrm{NaCl}$ and $\left(\mathrm{NH}_{4}\right)_{2} \mathrm{PO}_{4}$ caused a decrease in biosurfactant production. 

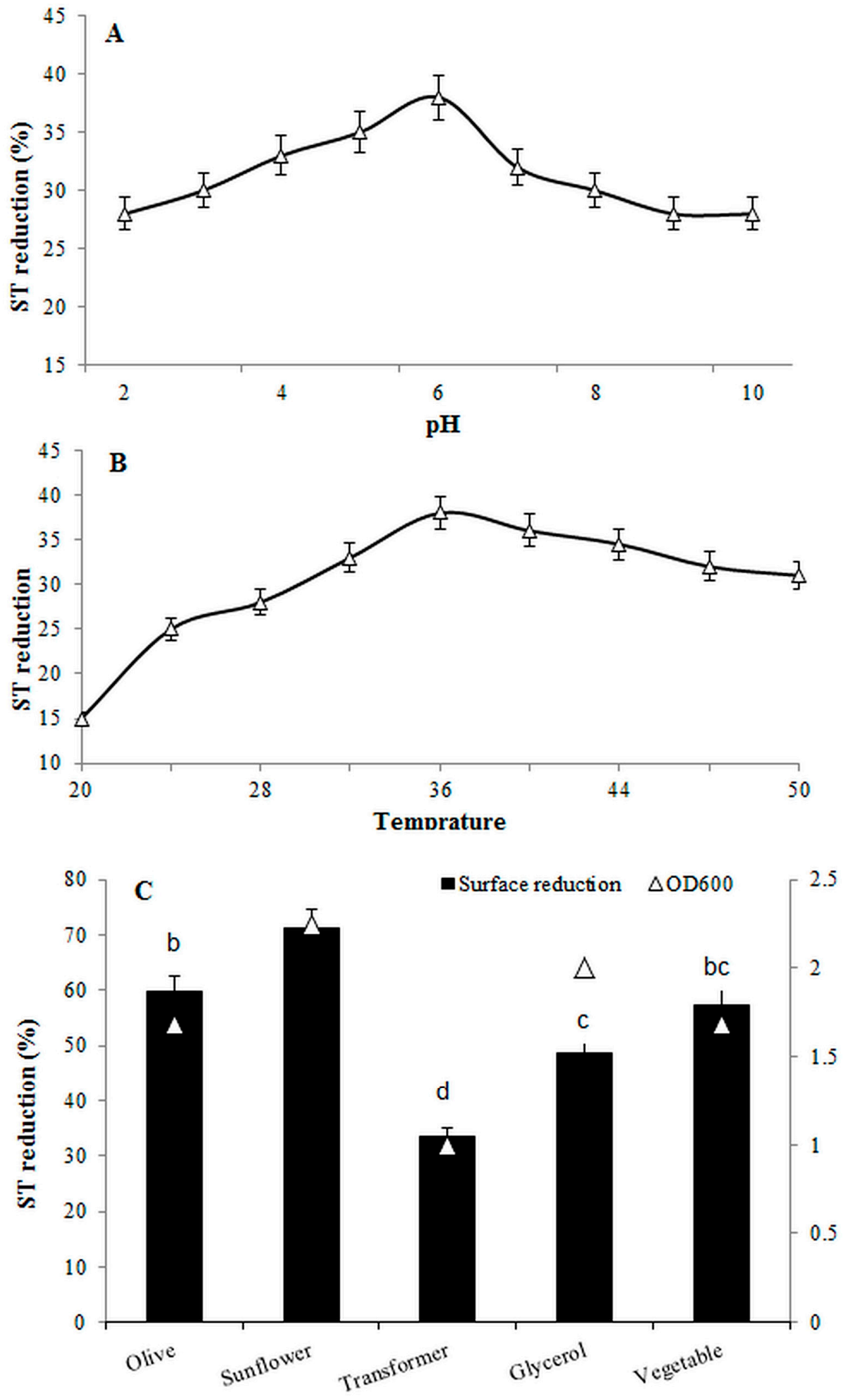

Carbon sources (oil), $1 \% \mathrm{v} / \mathrm{v}$

Figure 3. Influence of different ranges of $(\mathbf{A}) \mathrm{pH},(\mathbf{B})$ temperature and, (C) carbon source on surface tension (ST) reduction. 


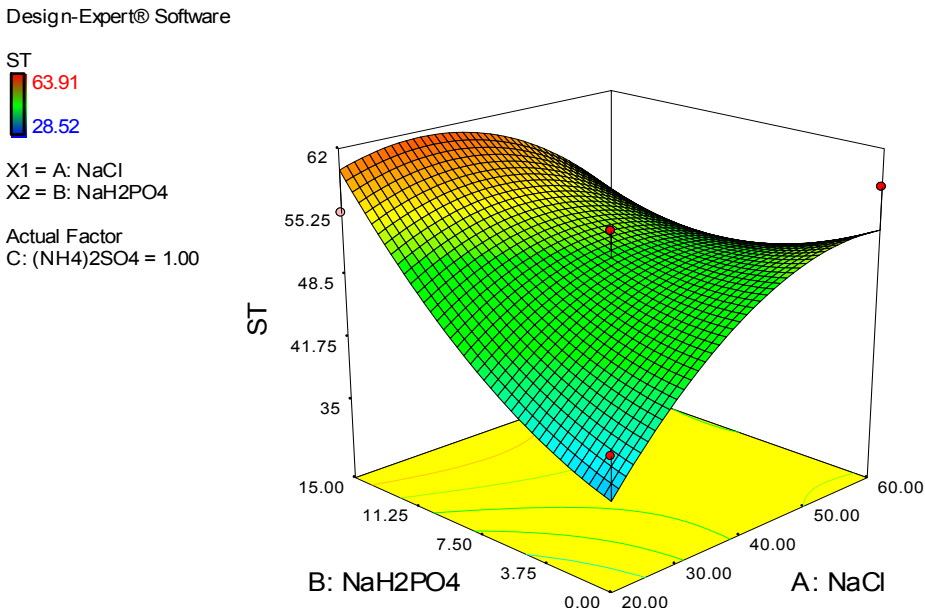

(a)

Design-Expert@ Software

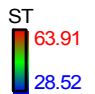

$\mathrm{X} 1=\mathrm{A}: \mathrm{NaCl}$ $\mathrm{X} 2=\mathrm{C}:(\mathrm{NH} 4) 2 \mathrm{SO} 4$ Actual Factor B: $\mathrm{NaH} 2 \mathrm{PO} 4=7.50$

5

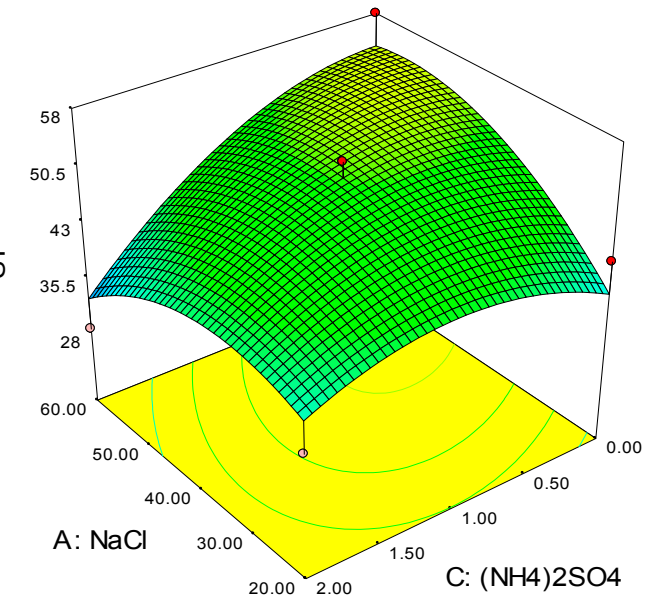

(b)

Design-Expert@ Software

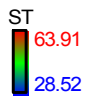

$\mathrm{X} 1=\mathrm{B}: \mathrm{NaH} 2 \mathrm{PO} 4$ $\mathrm{X} 2=\mathrm{C}:(\mathrm{NH} 4) 2 \mathrm{SO} 4$ Actual Factor A: $\mathrm{NaCl}=40.00$

5

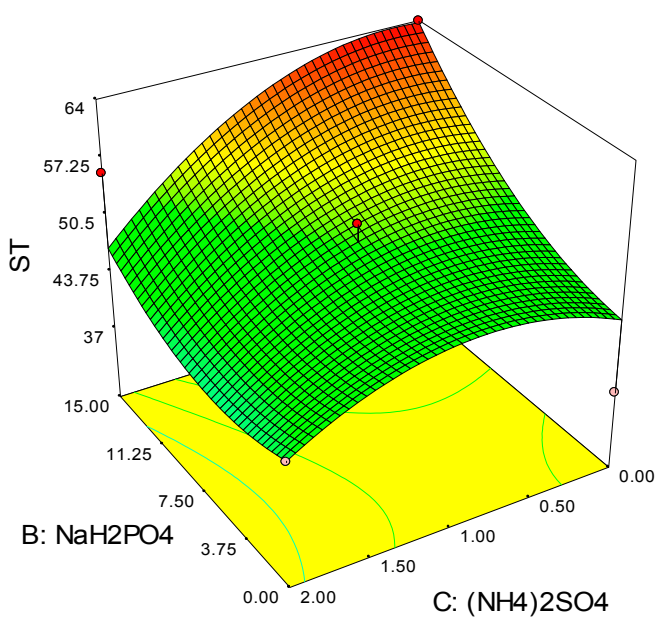

(c)

Figure 4. Influence of $\mathrm{NaCl}(\mathbf{a}), \mathrm{NaH}_{2} \mathrm{PO}_{4}(\mathbf{b})$ and $(\mathrm{NH} 4)_{2} \mathrm{SO}_{4}(\mathbf{c})$ on $\mathrm{ST}$ reduction (\%). 


\subsection{Solubilization Study}

The enhancement of the solubility of the biosurfactant at different concentrations was evaluated. As shown in Figure 5, at a concentration of $0.8 \mathrm{~g} / \mathrm{L}$, the solubility rate gradually increased followed by a sharp increase and then remained constant, regardless of an increase in oil concentration. Furthermore, the solubility rates at different lubricating oil concentrations were significantly different from each other. At the same emulsifier concentration, the solubility rate increased at lower oil concentrations; this result indicated the specific activity of the oil in the solubilization process, which affected the solubility of oil in water. However, the effectiveness of the biosurfactant to enhance water solubility was higher at $1 \%$ oil than that at 2 and $3 \%$. Furthermore, the percentage of solubility at a biosurfactant concentration of $2.4 \mathrm{~g} / \mathrm{L}$ decreased from 56.1 to $24 \mathrm{mN} / \mathrm{m}$ when the oil concentration increased from 1 to $3 \%$ (Figure 5). This result demonstrated that a high amount of hydrocarbon functions as a limiting factor during solubilization. The effects of different $\mathrm{pH}$ values on solubilization activity were also determined. The results showed that the biosurfactant activity decreased in acidic $\mathrm{pH}$, which is in line with the results obtained by Joshi et al. [31] who reported biosurfactant precipitation at $\mathrm{pH} 2$.

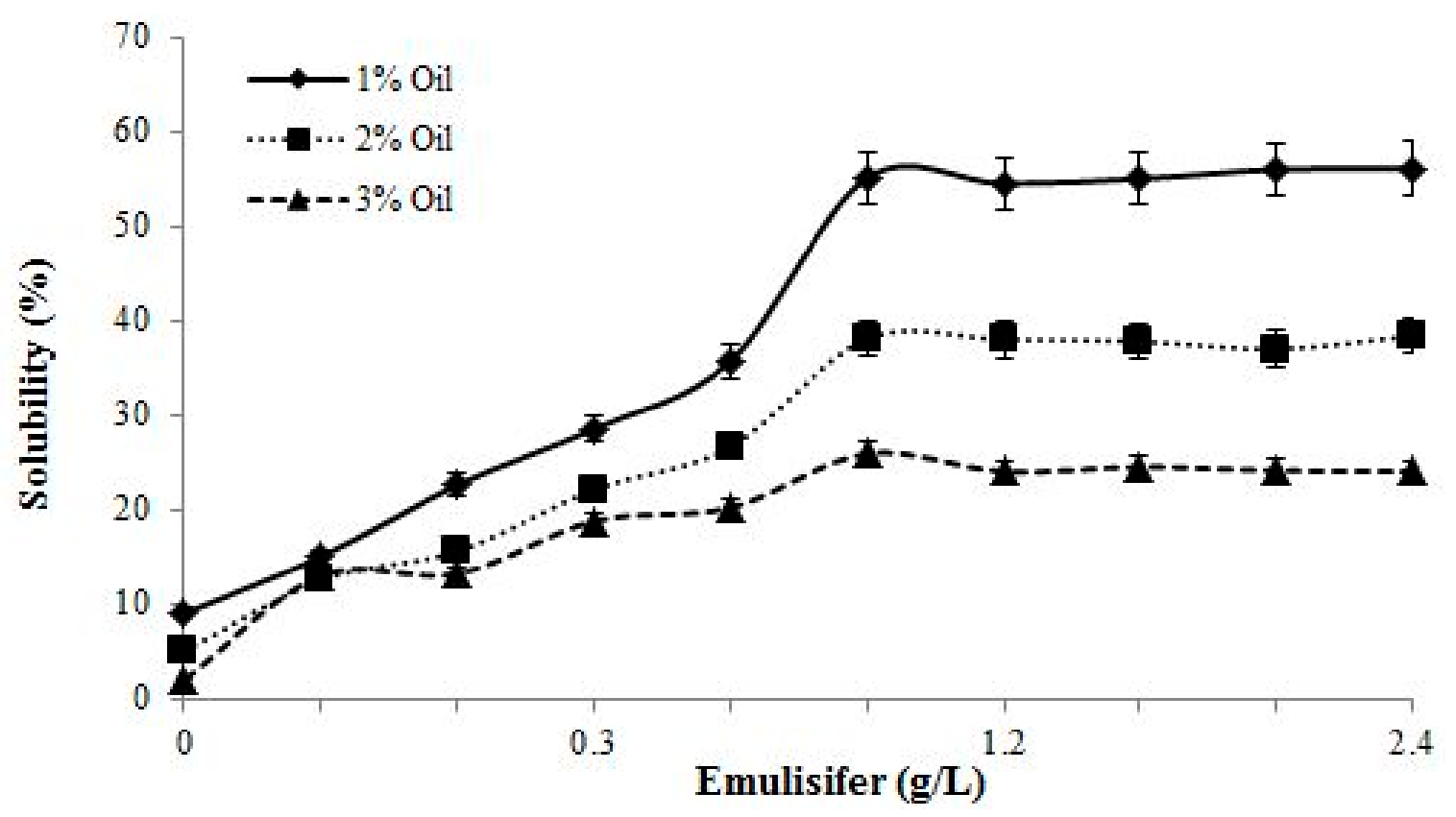

Figure 5. Effect of biosurfactant concentration on oil solubilization.

\subsection{Biodegradation of Lubricating Oil}

The potential of $B$. salmalaya 139 SI to utilize lubricating oil $(2 \% \mathrm{v} / \mathrm{v})$ as a source of energy and carbon was investigated for 24 days. Cultures were incubated at $35^{\circ} \mathrm{C}$, and samples were collected every four days to monitor the rates of oil degradation, microbial population, and ST. As shown in Figure 6, the strain was able to grow with $2 \%$ oil. The rate of oil degradation was determined via a gravimetric method, and the results illustrated that $19.6 \%$ of the oil was degraded during the first four days, with the maximum rate of degradation of $72.6 \%$ on Day 24 (Figure 6). After 20 days of incubation, the rate of oil degradation remained constant. The number of colony-forming units increased up to Day $16\left(3.6 \times 10^{6}\right)$, 
followed by a decrease until the end of the experiment; the value was up to $2.6 \times 10^{6}$ on Day 24 . The biosynthesis of the biosurfactant was determined by measuring ST. The amount of ST slowly decreased from $70.1 \mathrm{mN} / \mathrm{m}$ on Day 0 to $52.6 \mathrm{mN} / \mathrm{m}$ on Day 12, and the maximum reduction was observed on Day 20, reaching $37.4 \mathrm{mN} / \mathrm{m}$. Many studies have reported the ability of microbial surfactants to degrade hydrocarbons. In our previous study, we reported the potential of $B$. salmalaya 139SI for use in the bioremediation of crude oil waste [3,12]. Ayed et al., [2] reported that the biodegradation of diesel oil was enhanced by the addition of B. amyloliquefaciens An6 compared with an anionic surfactant and Tween 80. Therefore, decreasing ST with the addition of a biosurfactant at the water-air interface enhances and improves solubility, thereby reducing the partitioning of organic carbons from the oil phase into aqueous solution.

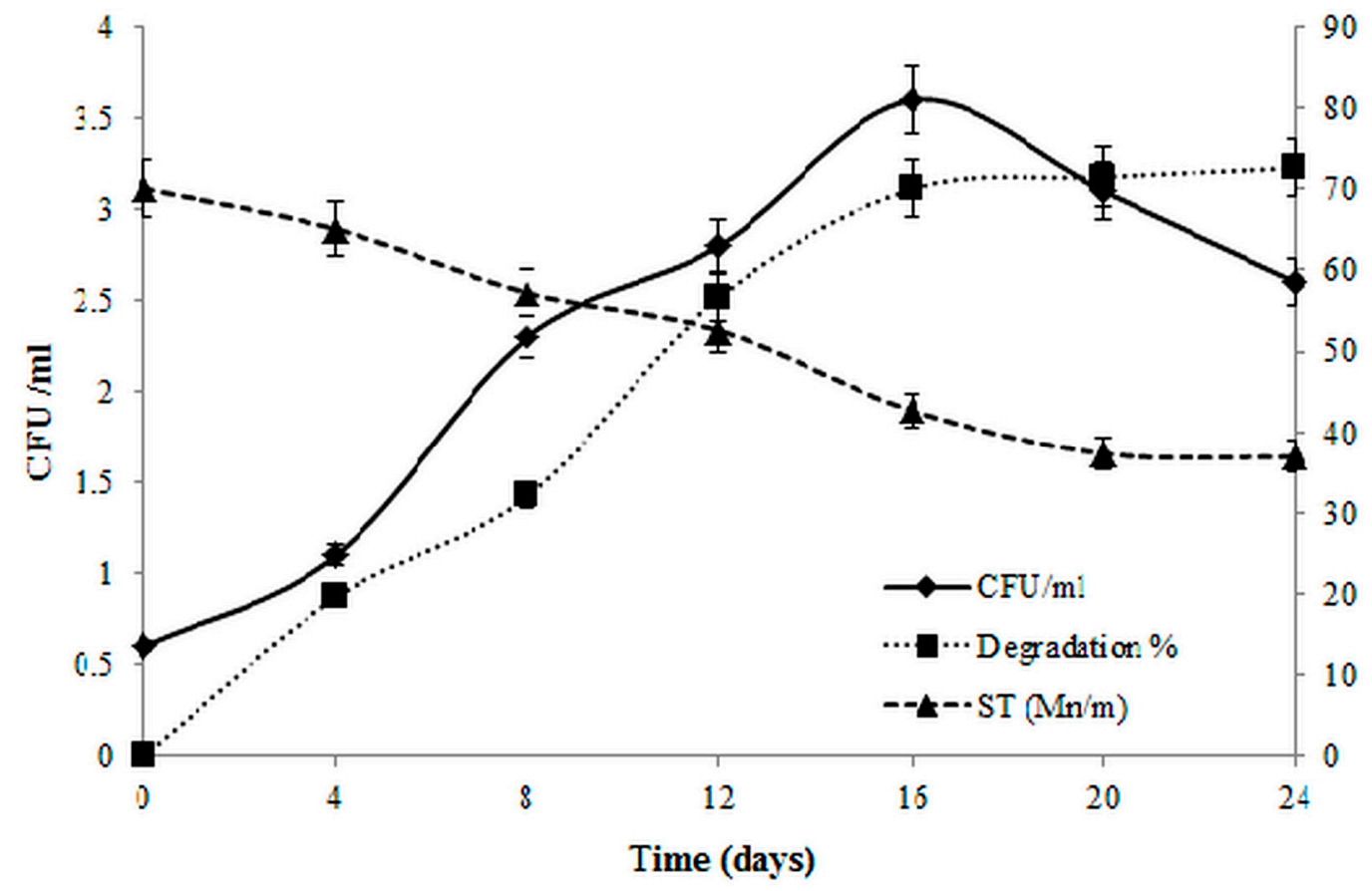

Figure 6. Changes in ST, biodegradation rate and strain growth during 24 days. Vertical bars indicate $\mathrm{SE}(n=3)$.

\section{Conclusions}

In this study, the optimal $\mathrm{pH}$ of the biosurfactant produced by $139 \mathrm{SI}$ was found to be 6.5 , and the highest ST reduction $\left(71.1 \%\right.$ ) was observed in a medium containing $1 \%$ sunflower oil incubated at $36{ }^{\circ} \mathrm{C}$. This biosurfactant demonstrated high emulsification activity and efficiency under extreme environmental conditions during remediation. Moreover, this biosurfactant likely enhanced the biodegradation and bioavailability of lubricating oil by reducing ST between the bacterial cell surface and oil. The biosurfactant produced by 139SI remained stable under various conditions, exhibited low toxicity, and enhanced the biodegradation of lubricating oil. Overall, the biosurfactant from B. salmalaya 139SI presents interesting features and therefore constitutes an alternative with potential use in several industries. 


\section{Acknowledgments}

This study was financially supported by University of Malaya Research Program (UMRP) with grant number of RP023A-14AFR.

\section{Author Contributions}

Arezoo Dadrasnia designed the study plan and guided the writing and analysis. Salmah Ismail contributed to data cleaning and extensive text editing. All authors read and approved the final manuscript.

\section{Conflicts of Interest}

The authors declare no conflict of interest.

\section{References}

1. Bolliger, C. Bioremediation of a Heating Oil-Contaminated Aquifer-Quantification Of Processes By Chemical, Biological, and Stable Isotope Analyses. Available online: http://e-collection.library.ethz.ch/eserv/eth:23731/eth-23731-02.pdf (accessed on 24 June 2015).

2. Ayed, B.H.; Jemil, N.; Maalej, H.; Bayoudh, A.; Hmidet, N.; Nasri, M. Enhancement of solubilization and biodegradation of diesel oil by biosurfactant from Bacillus amyloliquefaciens AN6. Int. Biodeter. Biodegr. 2015, 99, 8-14.

3. Dadrasnia, A.; Salmah, I. Bio-enrichment of waste crude oil polluted soil: Amended with Bacillus 139SI and organic waste. Int. J. Environ. Sci. Develop. 2014, 4, 241-245.

4. Ławniczak, Ł.: Marecik, R.: Łukasz, C. Contributions of biosurfactants to natural or induced bioremediation. Appl. Microbiol. Biotechnol. 2013, 97, 2327-2339.

5. Roy, A.S.; Baruah, R.; Borah, M.; Singh, A.K.; Deka Boruah, H.P.; Saikia, N.; Deka, M.; Dutta, N.; Chandra Bora, T. Bioremediation potential of native hydrocarbon degrading bacterial strains in crude oil contaminated soil under microcosm study. Int. Biodeter. Biodegr. 2014, 94, 79-89.

6. Pereira, J.F.B.; Gudiña, E.J.; Costa, R.; Vitorino, R.; Teixeira, J.A.; Coutinho, J.A.P.; Rodrigues, L.R. Optimization and characterization of biosurfactant production by Bacillus subtilis isolates towards microbial enhanced oil recovery applications. Fuel 2013, 111, 259-268.

7. Rufino, R.D.; de Luna, J.M.; de Campos Takaki, G.M.; Sarubbo, L.A. Characterization and properties of the biosurfactant produced by Candida lipolytica UCP 0988. Electron. J. Biotechnol. 2014, 17, 34-38.

8. Al-Bahry, S.N.; Al-Wahaibi, Y.M.; Elshafie, A.E.; Al-Bemani, A.S.; Joshi, S.J.; Al-Makhmari, H.S.; Al-Sulaimani, H.S. Biosurfactant production by Bacillus subtilis b20 using date molasses and its possible application in enhanced oil recovery. Int. Biodeter. Biodegr. 2013, 81, 141-146.

9. Al-Sulaimani, H.; Joshi, S.; Al-Wahaibi, Y.; Al-Bahry, S.; Elshafie, A.; Al-Bemani, A. Microbial biotechnology for enhancing oil recovery: Current developments and future prospects. Biotechnol. Bioinf. Bioeng. 2011, 1, 147-158.

10. Healy, M.G.: Devine, C.M.: Murphy, R. Microbial production of biosurfactants. Resour. Conserv. Recy. 1996, 18, 41-57. 
11. Neves, L.; de Oliveira, K.; Kobayashi, M.; Penna, T.; Converti, A. Biosurfactant production by cultivation of Bacillus atrophaeus ATCC 9372 in semidefined glucose/casein-based media. Appl. Biochem. Biotechnol. 2007, 137-140, 539-554.

12. Ismail, S.; Dadrasnia, A. Biotechnological potential of Bacillus salmalaya 139SI: A novel strain for remediating water polluted with crude oil waste. PLoS ONE 2015, 10, doi:10.1371/journal.pone.0120931.

13. Rufino, R.; Sarubbo, L.; Neto, B.; Campos-Takaki, G. Experimental design for the production of tensio-active agent by Candida lipolytica. J. Int. Microbiol. Biotechnol. 2008, 35, 907-914.

14. 14. Goncalves, C.: Rodriguez-Jasso, R.M. Adaptation of dinitrosalicylic acid method to microtiter plates. Anal. Methods 2010, 2, 2046-2048.

15. Luna, J.M.; Rufino, R.D.; Sarubbo, L.A.; Campos-Takaki, G.M. Characterisation, surface properties and biological activity of a biosurfactant produced from industrial waste by Candida sphaerica UCP0995 for application in the petroleum industry. Colloid Surface. B 2013, 102, 202-209.

16. Hamzah, A.; Sabturani, N.; Radiman, S. Screening and optimization of biosurfactant production by the hydrocarbon-degrading bacteria. Sains Malays. 2013, 42, 615-623.

17. Cunha, C.D.; do Rosário, M.; Rosado, A.S.; Leite, S.G.F. Serratia sp. Svgg16: A promising biosurfactant producer isolated from tropical soil during growth with ethanol-blended gasoline. Process Biochem. 2004, 39, 2277-2282.

18. Ruggeri, C.; Franzetti, A.; Bestetti, G.; Caredda, P.; La Colla, P.; Pintus, M.; Sergi, S.; Tamburini, E. Isolation and characterisation of surface active compound-producing bacteria from hydrocarbon-contaminated environments. Int. Biodeter. Biodegr. 2009, 63, 936-942.

19. Nitschke, M.; Pastore, G.M. Production and properties of a surfactant obtained from Bacillus subtilis grown on cassava wastewater. Bioresource Technol. 2006, 97, 336-341.

20. Bozo-Hurtado, L.; Rocha, C.; Malavé, R.; Suárez, P. Biosurfactant production by marine bacterial isolates from the venezuelan atlantic front. B. Environ. Contam. Tox. 2012, 89, 1068-1072.

21. Li, Y.; Zou, A.H.; Ye, R.Q.; Mu, B.Z. Effects of molecular structure on surfactant micellization activity. Acta Phys. Chim. Sin.2011, 27, 1128-1134.

22. Liu. Q.; Lin, J.; Wang, W.; Huang, H.; Li, S. Production of surfactin isomers by Bacillus subtilis BS-37and its applicability to enhanced oil recovery under laboratory conditions. Biochem. Eng. J. 2015, 93, 31-37.

23. Varadavenkatesan, T.; Murty, V.R. Production of a lipopeptide biosurfactant by a novel Bacillus sp. And its applicability to enhanced oil recovery. ISRN Microb. 2013, 2013, doi:10.1155/2013/621519.

24. Faria, A.F.; Teodoro-Martinez, D.S.; de Oliveira Barbosa, G.N.; Gontijo Vaz, B.; Serrano Silva, Í.; Garcia, J.S.; Tótola, M.R.; Eberlin, M.N.; Grossman, M.; Alves, O.L.; et al. Production and structural characterization of surfactin (c14/leu7) produced by Bacillus subtilis isolate 1sfm-05 grown on raw glycerol from the biodiesel industry. Process Biochem. 2011, 46, 1951-1957.

25. Sousa, M.; Dantas, I.T.; Feitosa, F.X.; Alencar, A.E.V.; Soares, S.A.; Melo, V.M.M.; Gonçalves, L.R.B.; Sant'ana, H.B. Performance of a biosurfactant produced by Bacillus subtilis lami005 on the formation of oil / biosurfactant / water emulsion: Study of the phase behaviour of emulsified systems. Braz. J. Chem. Eng. 2014, 31, 613-623. 
26. Moldes, A.B.; Paradelo, R.; Vecino, X.; Cruz, J.M.; GudiL, A.E.; Rodrigues, L.; Teixeira, J.A.; Domínguez, J.M.; Barral, M.T. Partial characterization of biosurfactant from Lactobacillus pentosus and comparison with sodium dodecyl sulphate for the bioremediation of hydrocarbon contaminated soil. Biomed Res. Int. 2013, 2013, doi:10.1155/2013/961842.

27. Joshi-Navare, K.; Prabhune, A. A biosurfactant-sophorolipid acts in synergy with antibiotics to enhance their efficiency. Biomed Res. Int. 2013, 2013, doi:10.1155/2013/512495.

28. Zhang, G.-1.; Wu, Y.-t.; Qian, X.-p.; Meng, Q. Biodegradation of crude oil by Pseudomonas aeruginosa in the presence of rhamnolipids. J. Zhejiang Univ. Sci. B 2005, 6, 725-730.

29. Huszcza, E.; Burczyk, B. Biosurfactant production by Bacillus coagulans. J. Surfactants Deterg. 2003, 6, 61-64.

30. Mnif, I.; Ellouze-Chaabouni, S.; Ghribi, D. Economic production of Bacillus subtilis SPB1 biosurfactant using local agro-industrial wastes and its application in enhancing solubility of diesel. J. Chem. Technol. Biot. 2013, 88, 779-787.

31. Joshi, S.; Bharucha, C.; Jha, S.; Yadav, S.; Nerurkar, A.; Desai, A.J. Biosurfactant production using molasses and whey under thermophilic conditions. Bioresource Technol. 2008, 99, 195-199.

(C) 2015 by the authors; licensee MDPI, Basel, Switzerland. This article is an open access article distributed under the terms and conditions of the Creative Commons Attribution license (http://creativecommons.org/licenses/by/4.0/). 